\title{
Pragmatics and Semiotics: The Relevance of Addressee Expectations in the Translation of Newspaper Texts
}

\author{
Eva Samaniego \\ University of Alfonso X El Sabio
}

esamafer@uax.es

\begin{abstract}
Newspaper and advertising texts have traditionally been 'difficult children' for translation studies to deal with, mainly for one thing: they seem to be systematically norm-flouting. In fact, in traditional approaches, they were customarily quoted as typical examples of 'free translation', 'unfaithfulness' or, in some cases, outright creation of a new text. Although it is true that these texts present certain translation peculiarities, this is by no means a random process of transfer where translators set their 'wild imagination' to work. Quite on the contrary, it is argued here that it is precisely these texts that demonstrate how systematically translators are capable of forecasting the average target recipient and of adapting the texts to reader expectations by fulfilling pragmatic and semiotic considerations in the process of transfer; these seem to be the two guiding parameters for the occurrence of 'translation incidences' in newspaper binomials. To prove this claim, we present the results obtained from a descriptive study carried out with a selection of semiotic and pragmatic factors on a corpus of newspaper texts published by The Guardian and their subsequent translations into Spanish, published by El Mundo.
\end{abstract}

\section{Introduction}

According to current translation theories, a translation (as a product) would be defined as any text accepted as received as such within a given polysystem regardless of its quality, fidelity to the original, or even the existence of an original (see Toury, 1981: 19, 1985:20 
and 1995; Hermans, 1993: 75-76; Van den Broeck, 1978; Chesterman, 1993: 2, etc.). Although there are still theoreticians who feel uncomfortable with this postulate ${ }^{1}$ (see Nord, 1991: 28), the fact remains that rather frequently translators, translation instructors and researchers come across TTs that seem to have little or nothing in common with their corresponding STs, and yet are presented - and accepted-as adequate equivalents.

This postulate is a natural consequence of the drastic turn experienced by translation studies in the last twenty years, when prescriptive studies have been gradually replaced by descriptive studies (Toury, 1981, 1985 and 1995; Hermans, 1985a, etc.), which do not focus on what translations should be like, bur rather what they really are (Toury, 1985: 28):

within DTS [descriptive translation studies], then, translational problems are always reconstructed rather than given. They are reconstructed through target-source comparison rather than on the basis of the source text alone, or even of the source text in its relation to the overall possibilities of the target language to recode its (relevant) features (that is, on the basis of the initial 'translatability' of the source text into the target language).

Consequently, source-oriented approaches are increasingly disregarded to favour targetoriented $^{2}$ studies (Toury, 1985: 25; Snell-Hornby, 1988: 44; Baker, 1993: 239), and this process has had an immediate impact on the concept of equivalence, which is now understood as the relationship existing between a source text (or source item) and a target text (or target item) which is "redefined for each and every act of translation" (Chamosa González, 1997: 44,45, my translation). Thus, translemic equivalence does not pursue 'perfect versions' but rather 'acceptable versions' (Rabadán Álvarez, 1991a: 45), in sharp contrast with former prescriptive parameters of loyalty to the ST (Toury, 1995: 35). An example from chemistry is illustrative of this particular link between the source and the target text: like isomers, or bodies which having identical chemical composition present differing physical properties (Considine, 1974, Parker, 1991), the ST and the TT share a similar composition ('content' according to Rabadán Álvarez, 1991a), but are, by definition, physically different ('differing formal appearance', Rabadán Álvarez, 1991a, my translation).

These basic premises, which were rather controversial at one time, are now shared knowledge; yet the fact remains that even though most translation theorists and instructors are ready to accept these principles - or have already accepted them-, few of them apply them realistically. Most of us instinctively tend to judge translations in terms of their source texts, doubtless due to a traditional training, and when it comes to teaching translation, the situation is still worse (Hurtado Albir, 1999). Basically, what is taught at universities is literal translation ${ }^{3}$, with rare instances of creativity encouragement, as Hurtado Albir has very justly observed: "(...) most of the translation problems commented on in class are of a linguistic nature (...) and the predominant notion of translation is literal in nature" (Hurtado Albir, 1999: 16, my translation).

Not too unfrequently, the creativity process in translation is hindered by the undeniable fact that many instructors simply want to test the student's comprehension of the SL, not his/her translation skills ('pedagogical translation' for Hurtado Albir, 1996b: 33). As a 
result, far too many instructors offer 'a correct version' in class for students to modify theirs (Hurtado Albir, 1999: 17). Obviously, this is a model wanting in nature.

Unfortunately, the predominance of linguistic models and the still pervading magisterial lectures where students are expected to adopt a passive role (Hurtado Albir, 1999:28) result in a grossly inadequate but commonly accepted paradigm of translation which in practice rules out any equivalence other than the merely literal. In fact, the prevalent model is so much semantically based, that many students tend to believe that texts contain meaning they have to guess at, whereas the correct approach would be for them to accept that texts vehicle meaning; under this assumption, text analysis extends beyond semantics to focus on textual strategies, which is a much more holistic approach (Séguinot, 1999: 87). As Rogers (1999: 105) puts it, the implication of this context-independent approach to translation is that students believe that "translation consists (...) of a simple cross-linguistic substitution exercise".

The inclusion of conceptual, textual, pragmatic, semiotic and communicative models of translation in the current teaching syllabus, as many theorists have long been claiming (Rabadán Álvarez \& Fernández Polo, 1996; Rabadán Álvarez, 1996; Hatim \& Mason, 1990 and 1997; Hurtado Albir, 1996a, 1996b and 1999; Neubert \& Shreve, 1992 to quote but a few), would pave the way for a more open and realistic approach to equivalence, which would contemplate, as Toury had foreseen as early as 1985, the inclusion of what were traditionally called 'anomalous equivalences' or 'exceptions to the rule', such as 'zero solutions' or the creation of linguistic material from $\langle\varnothing\rangle$ (Toury, 1985; 25).

Armed with these basic principles and with an open mind, it is our aim here to approach the motivations and patterns underlying the concept of equivalence applied in the text binomials studied in the corpus, which is made up of STs published by The Guardian and their translations published by $E l$ Mundo.

\section{Newspaper texts}

We intentionally avoid more specific alternatives for the general term 'newspaper text' as used in this heading, since to us other terms such as 'article', 'report', 'editorial', etc. point to concrete subgenres. In our opinion, 'newspaper text' enjoys the benefit of being an umbrella term that covers all the differing genres and subgenres included in this category.

Many newspaper texts are readily identified and assigned a label by native speakers; according to Biber (1989: 39), this means that they would conform a 'genre': "genres are text distinctions recognized by mature adult speakers reflecting differences in external format and situations of use". Texts belonging to the same group have certain functions, characteristics and features that are shared and at the same time peculiar to them. This principle has been sufficiently demonstrated and requires no further discussion here (see Crystal \& Davy, 1969/1990; Van Dijk, 1985a, 1985b, 1988a: 1-2, 1988b and 1997; Jucker, 1992; Stubbs, 1996; Fowler, 1991; Keeble, 1994; Vilarnovo \& Sánchez, 1992; 
Casasús \& Núñez Ladevéze, 1991; López García, 1996; Martín Vivaldi, 1973/1984; Martínez Albertos, 1989; Martinez Vallvey, 1996, etc.).

However, what is of interest to us in this paper is to find out the specific features that distinguish these texts from potentially similar instances of texts (see Nord, 1994 and 1995). Coseriu and Lázaro (quoted in Vilarnovo and Sánchez, 1992: 155-161) argue that the key distinguishing feature of newspaper texts is their instrumentality: while literary texts 'use up' their chief intention, newspaper texts go further, since they have the permanent reference of a real outside world to which they are bound (see Albaladejo Mayordomo, 2000: 1). Literature can create autonomous worlds; newspaper texts are not initially conceived with that purpose. Typically, newspaper texts take on identity only with reference to this 'external entity' (what López García, 1996 metaphorically calls 'textual anchorage', my translation), and are therefore judged in terms of their correspondence with the event. they are about (Vilarnovo and Sánchez, 1992: 157). This constitutes their 'discursive individuality" (Van Dijk, 1988a: 1-2; see also López García, 1996: 16-30): "media discourses in general, and news reports in particular, should be accounted for in their own right, e.g. as particular types of language use or text and as specific kinds of sociocultural practice". Besides, these texts exhibit a pronounced pragmatic character (Vilarnovo and Sáchez, 1992) and are punctual in nature insofar as they focus on current events and address a spatially and chronologically restricted specific reader; this is responsible for their ephimerality (see Gaudino-Fallegger, 2000: 2). In sum, they tend to lack historical perspective and are, by virtue of this transitory character, perishable.

In our specification of the distinguishing features of newspaper texts, we suggest eight major points that may capture the essence of this particular genre:

i) these texts depend heavily on their degree of 'anchorage' to a referent in the outside world;

ii) they are instrumental and have a marked pragmatic character;

iii) they are addressed to a spatially and chronologically restricted audience and this results in their ephimerality;

iv) they try to interpret the present, the immediate past or the future, but usually lack historical perspective;

v) they tend to show a marked political stance and ideology bias; the information is aimed at a particular reader with defined beliefs, and thus the information adapts itself to the targeted reader;

vi) there is a pronounced level of shared knowledge in the ideology level, that is, newspapers and their readers usually share common ideological stances; on the other hand, shared knowledge is low at the informative level, since most newspaper texts assume that their readers do not necessarily possess any information on the event or news item a text is about;

vi) they have a specific format and periodicity;

vii) they have distinctive space restrictions (Vilarnovo and Sánchez, 1992, Hetherington, 1981, etc.). 
An understanding of the nature of newspaper texts requires a brief discussion on the relative status of newspaper headlines as independent genres. There are two alternatives: to treat these textual elements as separate autonomous genres with distinctive features, or to include them within the more general group 'newspaper text'. The literature consulted seems to agree that headlines constitute an independent genre on their own (Nord, 1994: 85; Núñez Ladéveze, 1995: 59-68; Shveitser, 1997: 137-157). In this sense, Crystal and Davy (1969/1990: 180) leave no room for any doubts: "headlines of course are a separate study in themselves, being radically different from the rest of newspaper reporting language" (my emphasis). For Nord (1994: 88), headlines have certain functions which differ from the ones typically associated with other newspaper texts: headlines identify texts, set up the first contact with the intended audience, inform the reader about the genre they belong to, describe the text content or some of its aspects, convey the sender's opinion or appraisal of the situation at hand and invite the reader to approach the text ("estructura captativa" for Gaudino-Fallegger, 2000: 2). Additionally, headlines seem to fulfil the seven traditional conditions of textuality: intentionality, acceptability, situationality, informativity, intertextuality, coherence and cohesion ${ }^{4}$ (Beaugrande and Dressler, 1981), a fact which seems to indicate their status as a separate genre.

Núñez Ladéveze (1995: 59-68) agrees on the special nature of headlines, but is firm in his belief that they are inseparable from the body of the text, to which they are inextricably conjoined by coherence and subject matter reference, among other factors. Still further, many native speakers recognize both the body of the text and the headline as one genre and would not be willing to split them or to group them as different categories. However, Van Dijk in his already classic model of news structure (1988b: 55), separates headlines and leads from the body of the text (which he calls the 'story').

This is indeed a very difficult decision to make, because each of these options may change the whole approach. But there is a way out of the deadlock: why not take the view that both headlines and the body of texts are subgenres inserted into the more global genre 'newspaper text'? After all, it is noteworthy that this is what native speakers seem to have in mind when they are asked to describe an archetypical newspaper text: the headline plus the body of the text. And a second advantage is that this solution seems to be in line with the relatively recent findings of several researchers on the multifunctionality, hybridization and complexity of genres and text typologies (Hatim and Mason, 1990: 138 and 1997; SnellHornby, 1988: 31; Biber, 1989; Sigley, 1997; Crystal and Davy, 1969/1990: 63; Roberts, 1992; Reiss and Vermeer, 1996).

On the basis of this fundamental premise, we conclude that the textual unit "newspaper text' is made up of three items: two linguistic elements, -the headline (plus the rest of elements included in it, such as leads, deck heads, subheads etc.) and the body of the textand one iconic element, the graphic accesories (Martínez Vallvey, 1996: 87-115), integrated by non-linguistic elements, such as photographs, icons, etc. Each of these items may reach, given certain conditions, the category of autonomous genres. 


\section{Pragmatics, Semiotics and newspaper text translation}

According to Halliday and Hasan (1989), context ${ }^{5}$ is integrated by three dimensions: communicative (field, tenor and mode), pragmatic (intentionality, implicatures, inferences, etc.) and semiotic (genres, text types, intertextuality, etc.), a division which would later be taken up by Hatim and Mason (1990 and 1997) and others in translation studies.

Though highly valuable as a classification, what we find faulty in it is the difficulty of analysing these dimensions as relatively separate entities, as the model seems to imply. To us, the three dimensions are very closely -almost inseparably - interconnected. Not that the authors ever put forward the opposite, but this 'sorting' seems to suggest that the dimensions are somehow related, but not closely interconnected. In many cases the pragmatic dimension determines the semiotic rendering of the text, or the other way round; or may be the communicative dimension is a linguistic expression of the pragmatic and semiotic components. In this line of thought, we depart from the following assumption: the pragmatic, communicative and semiotic dimensions are much more closely interconnected than what is usually assumed in translation studies.

However, since the analysis we intend to carry out has to be restricted by nature in order to achieve manageable results, we have chosen two dimensions only, pragmatic and semiotic, and therefore we had to separate these two dimensions -though reluctantly - from the communicative one.

Pragmatics, which can be defined as the study of "rules and principles which govern language in use" (Malmkjær1991: 354), devotes its efforts to the analysis of context and its surrounding factors in any communication event. Semiotics is the science that analyses, among other things, the value of texts as tokens and their relationship with intertextuality, genre and text type parameters (Hatim and Mason, 1990 and 1997). As stated above, pragmatic and semiotic factors are very closely interconnected; for instance, if a text fulfils all textuality conditions, then it will be a text that will logically follow the co-operative principles, amongst them the maxim of quantity, and will try to make the contribution as informative as is required for the current purposes of the exchange and not more informative than is required (Leech, 1983, Levinson, 1983). But then, semiotics is involved here as well, since genres impose certain restrictions on text format and information distribution; logically, text senders adhere both to pragmatic and semiotic textual requirements when producing their text.

Since pragmatics studies language in context, it is important to elaborate a little on the extratextual factors that are relevant in the communication process ('contextual' for Nord, 1991, Snell-Hornby, 1988: 69; 'situational' for Roberts, 1996b or Lambert and Van Gorp, 1985: 51; 'text-external' for Hartmann, 1980: 19 and 'text-environmental' for Nord, 1992: 44).

There are several models of text analysis in translation studies that are worth mentioning, amongst them Rabadán Álvarez, 1991a ('invariante metodológica'); Nord, 1991 ('recursive model') and 1992; Reiss, 1992; House, 1981 [1977]; Hatim and Mason, 1990 and 1997; Reiss and Vermeer, 1996; Roberts, 1996b; Snell-Hornby 1988 and a 
modest attempt by Lambert and Van Gorp in 1985. Since an analysis of these models falls outside the scope of this article, we will only say here that, after a detailed study of these hypotheses, we may define 'extratextual factors' here as those involved in the communication process ${ }^{6}$ and which can be guessed at "simply by observing the situation in which the text is used" (Nord, 1992: 43). More specifically, the parameters we will consider are: 'sender', 'receiver', 'channel' (see Bühler, 1934; Jacobson, 1960; Hartmann, 1980: 14-15; Hatim and Mason, 1990: 135 or Gómez Soliño, 1996: 45,), 'medium' ('mode' for Hatim and Mason, 1990 and 1997), 'message' (which includes texts and their production circumstances), 'system' (culture where the message is produced; 'code' for Gómez Soliño, 1996 and Hartmann, 1980), and something unique to the translation process, 'client' of the translation process ${ }^{7}$ ('initiator' for Hatim and Mason, 1997: 11, Hewson and Martin, 1991: 123, Nord, 1992: 39-40; 'agent' for Sager, 1994: 321, in Shuttleworth and Cowie, 1997: 7). These are all variables with relevance in the communication process, be it translation or any other type of communication.

As for the semiotic parameters analysed in this article, there are three that are particularly interesting: intertextuality, genres and text types. We will restrict our study to intertextuality and gender, since the analysis would otherwise be too broad and generalistic.

The question of genre and text type is far too complex and controversial to be dealt with in a few paragraphs; we will only cover here the conclusions reached on this issue by recent research $^{8}$ (for a detailed study of current genre research see Samaniego Fernández, 2000: 96-120). We will define 'genre' as conventionalized abstract models of texts -associated with certain social situations- which a native speaker is capable of identifying (see Birch, 1995: 7, Hatim and Mason, 1990: 69 and Colina, 1997: 336) on the basis of characteristic features and patterns (like specific formats or certain information distribution, especially for rigid communication formats such as legal or administrative texts). In fact, what most native speakers have in mind when asked about genres is textual 'prototypes' (Biber, 1989: 5), that is, hypothetical paradigmatic models of texts with no actual occurrence in language. Texts with actual existence in a language and closely resembling these hypothetical mental contructs would be called 'model texts' (Hatim and Mason, 1997; Isenberg, 1987).

Intertextuality (or 'hypercodification' for Eco, in Lozano et al., 1982:21) concerns "the way in which the use of a certain text depends on knowledge of other texts" (Malmkjær, 1991: 469). For Hatim and Mason (1997: 17-18) it includes "all those factors which enable text users to identify a given text element or sequence of elements in terms of their knowledge of one or more previously encountered texts or elements" (see also Rabadán Álvarez, 1996: 98 and Roberts, 1996b). The notion of intertextuality is extremely important because the interdependence of texts is responsible for the evolution of genres.

Once the pragmatic and semiotic factors relevant to the communication process have been defined, we will move on to focus on the contextual factors mentioned above as applied to the two newspapers studied here, so as to discover how they impinge on the translation process. Of the seven features relevant to the communication process (sender, recipient, etc.) we have chosen the ones that, in our opinion, stand in a very close relationship with pragmatics and semiotics: sender, receiver, message and system. 


\subsection{Sender}

In this case, the translator will have to guess at the relevant features of the ST sender, since the only information overtly offered in newspaper texts is the name of the ST author. However, the translator can deduct - or rather, induct-certain data on the text sender by making use of the linguistic material within the text (for example, geographic variation, social variation, field, etc.); as for the TTs, the name of the translator does not appear in the texts of the corpus.

\subsection{Receiver}

In order to approach the average reader for The Guardian on the one hand and El Mundo on the other hand, we have resorted to the 'predictors of readership' as applied by Willis (1990: 49-58). The author argues that there are be five possible types of newspaper users: 'instrumental', who read to be informed; 'opinion makers', who read to have a critical opinion; 'readers for pleasure', who find newspaper reading an enjoyable activity; 'ego boosters', who read with the sole purpose of reassuring their image or status and 'scanners', or asystematic readers whose interest in newspaper reading is occasional. The average Guardian reader belongs, according to Willis, to the following categories (in this order): 'opinion maker', 'instrumental', 'pleasure reader' and, given the particular socio-cultural features of quality newspapers in Great Britain, a share of 'ego booster' (see Oakland, 1989/1995). For $E l$ Mundo (in the opinion of Jorge Fernández, deputy manager), its average reader belongs to these categories (in this order): 'opinion maker', 'instrumental', 'pleasure reader' and a small share of 'scanner'. As can be seen, the 'ego booster' type does not exist in the Spanish polysystem, due to the different socio-cultural role played by quality newspapers in the British polysystem with no real equivalence in the Spanish environment. Additionally, given the particular identification of The Guardian with educated readers, the 'scanner' type is rare: reading these papers is not at anybody's reach: they are very difficult to read without rather extensive education. In sum, the identification of The Guardian with a high (middle) class educated reader disappears for its Spanish counterpart.

There is a second aspect which calls for analysis here: the socio-cultural distinguishing features of the average ST and TT reader. A questionnaire was sent to The Guardian and El Mundo, and the results were as follows:

- The Guardian: its average reader would belong to the higher middle class, would have university training (probably postgraduate studies) and would be equally divided into men and women. The targeted reader would cover an age range of 15-44 years and would not necessarily be specialized in any subject matter;

- El Mundo: its average reader would belong to the middle class or lower middle class, would not necessarily have university training and would be equally divided into men and women. The targeted reader would cover an age range of 18-60/70 years and would be lay in most subject matters ${ }^{10}$. 
The answers obtained from the newspapers under study show quite clearly that the targeted reader of El Mundo has a much lower level of specialization than that of The Guardian; the Spanish newspaper is also much more flexible and comprehensive in terms of age and social class. In textual terms, this indicates that: i) shared knowledge between sender and receiver is much lower for El Mundo than for The Guardian; as a result of this, ii) El Mundo makes many more textual, pragmatic and semiotic concessions to its reader which The Guardian consciously ignores, taking for granted that its reader shares a considerable portion of the information with the text sender.

As will be seen later, these two essential contextual features are mostly responsible for the concept of equivalence chosen by translators in the transfer of these texts.

\subsection{Message}

Within the wide range of text-internal parameters with relevance on the message (see Nord, 1991 and Samaniego Fernández, 2000), we will concentrate here on intratextual coherence (more specifically, text distribution) and translation inequivalences at the lexical and phraseological level (see Rabadán Álvarez and Guzmán, 1987), which will be dealt with in depth in section 5 .

Coherence concerns "the way in which the things that the text is about, called the textual world [concepts + relations], are mutually accessible and relevant" (Malmkjær, 1991: 465, my addition). Most common relations can be classified in terms of two major notions: causality relations and time relations.

As for translation inequivalences, they consist of elements -at any level- which systematically pose difficulties in translation (see Even-Zohar, 1981 and 1990; Rabadán Álvarez, 1991a). Some well-known examples are metaphors, puns, culturally-bound terms, etc.

\subsection{System}

The two newspapers studied in this article have been published in rather different sociocultural contexts as has been mentioned above (Freeborn, 1996: 265; Oakland, 1989/1995: 270; Dunnet, 1988: 102; Samaniego Fernández, 2000: 364). Is then a comparison possible between The Guardian and El Mundo to evaluate the relevant factors involved in the production of each? The probable answer to a comparison in absolute terms would be 'no', but it can be attempted in more relative terms, even if the terms of the comparison are different in nature, which is what we are very likely to expect.

It is essential to establish a common ground for the comparison, in this case based mainly on extratextual factors (Nord, 1991), which tend to be more holistic. First, there is the division in Great Britain between 'tabloids' (or 'popular papers') on the one hand and 'quality newspapers' on the other hand (Dunnett, 1988: 107; Oakland, 1989/1995: 267, etc.). This very first feature results in statistically misleading data; the UN Statistical Yearbook figures for newspaper reading in Great Britain are the highest in Europe ${ }^{11}$ (1993: 
194); this should not let us be taken in so easily, since it is caused by the well-known large tabloid runs. This means that in spite of the higher figures for newpaper reading in Great Britain, the fact is that they are merely quantitative, not qualitative; in consequence, it cannot be precipitously said that there is a higher level of press reading population in Great Britain, a statement that does not reflect the underlying reality of press readers in Great. Britain: the vast majority read tabloids, which would not be considered 'press' in most European countries.

The division in 'tabloids' and 'quality press' is based on three factors: content, format and price. As for content, tabloids tend to be sensationalist and superficial (Oakland, 1989/1995: 274) ${ }^{12}$, whereas quality papers tend to analyse news in depth, include art, literature and culture reports in general and encourage readers' critical judgment. As a result, tabloids are generally associated with the working class or lower middle class, whereas quality papers are usually read by the higher middle classes and above ${ }^{13}$ (Oakland, 1989/1995: 274-275). In terms of format, quality papers and much larger ('broadsheet'; Oakland, 1989/1995; "sábanas" in Spanish, De la Serna, 1996: 47); finally, quality papers are slightly dearer than tabloids, since they have to invest a considerable quantity of their profits in marketing campaigns (Oakland, 1989/1995: 274), qualified staff and resources.

The truth remains that eventually it is extremely difficult to compare both newspapers, given that they are set in drastically different backgrounds: first, there does not seem to exist anything similar to tabloids in the Spanish environment; only romance magazines seem to share some features with tabloids, but obviously they do not have the same social role and cannot be equalled; additionally, there are romance magazines in Great Britain as well, but they have a different status. A second reason preventing this comparison is the run figures of newspapers: Marca and $A s$, both sports newspapers, head the selling list in Spain; again, it is difficult to find anything similar in Great Britain: sporting events are usually covered by tabloids, and the few sports magazines that are published do not have the same social role. Finally, if we exclude Marca and $A s$, there are five national newspapers in Spain as against ten in Great Britain, figures that are misleading if used to interpret both social realities.

In sum, the general comparison between both publications as far as their difference range permits is the following:

- circulation: during the period 1995-1997 The Guardian sold around 400,000 papers a day, some 100,000 more than ElMundo (Asociación para la Investigación de Medios de Comunicación A.I.M.C.; Audit Bureau of Circulations);

- price: both newspapers have very similar prices;

- ideology and reputation: even though there is a financial relationship between both papers, which makes them share a basic ideology ${ }^{14}$, The Guardian remains a centre-left high quality paper, whereas the informal opinion of fifteen polled Spanish informants was that ElMundo has of late invited a sensationalism which was not welcome when it started. It now seems to have moved towards a centre-right position (in fact, it published President Aznar's election program for $1996,26 / 03 / 95$ and $27 / 03 / 95$ ). Its approach to certain news has been 
described by the informants as 'yellowish', something which in fact would be more appropriate for a tabloid than for a quality paper;

- format: The Guardian is a broadsheet paper which doubles El Mundo in size.

\section{The corpus and the analysis}

To prove our claim that newspaper text translations are chiefly adequate renderings and not unfaithful versions, regardless of the number of changes observed in the TTs, we have selected a total of 67 newspaper texts, which constitute the whole of texts originally published by The Guardian (U.K. edition) and subsequently translated and published in $E l$ Mundo from the $1^{\text {st }}$ of July to the $31^{\text {st }}$ of December, 1995. These texts integrate half of a much more detailed study on a larger corpus developed in a doctoral thesis (Samaniego Fernández, 2000).

The total number of words in the binomiais studied is 189,823 . The extension of the texts is quite varied: the iongest text is English is 2,941 words, in Spanish 2,754; the shortest in English is 286, in Spanish 112. This means that the average text in English is 1,613 words long, 1,433 in Spanish.

We are conscious that we are not working with a large corpus and that this collection of texts would, from the point of view of corpus linguistics, probably be called a 'sample'; however, we have made use of most of the steps suggested by Sinclair (1991) for corpora building, since we find them equally applicable to our compilation process. Firstly, we electronically stored the texts, and the option chosen was the "adaptation of material already in electronic form" that Sinclair (1991: 14) mentions , since the texts were retrieved from the CD-ROMs of each of the publications. The initial files were in ASCII format, which was later replaced by Winword 6.0 format in order to make use of some of the tools provided by this software (item search, column format to show the texts in parallel, etc.); this is the 'manipulation' stage that Sinclair mentions (1991: 21). The appropriate copyright permissions were also requested and granted ${ }^{15}$ (Sinclair, 1991: 15). The next step was to restrict the corpus chronologically (Sinclair, 1991: 18); as mentioned above, the chosen period of study was six months. In this case, the reference of date is bound to STs and TTs, given that TTs were chronologically subsequent to STs and there was the possibility that they might have been published later, outside the limits of the period established. This means that the corpus includes only those texts whose original and translation were published within the selected period.

Among the general characteristics of the texts studied, there a few that are worth mentioning:

i) all the binomials are 'direct translations', that is, translations from a second language into the mother tongue, in this case the translator's, in line with the 1976 Nairobi Declaration ${ }^{16}$; though this was originally meant for translation processes, we think it equally applicable to the process of analysing binomials; 
ii) all TTs are 'covert translations' (House [1977], 1981: 189, Rabadán Álvarez, 1991a: 299), that is, they are not readily identified as translations as many of them are presented in a format subject to misinterpretations. The external 'mark' of the translation comes immediately after the lead, as indicated below:

\section{JONATHAN FREEDLAND}

\section{THE GUARDIAN/EL MUNDO}

This is clearly ambiguous: fifteen Spanish subjects were asked and 13 of them agreed that they would not interpret this as the 'typical mark' of a translation; some even thought that the author name appearing would belong to the correspondent of El Mundo in Great Britain. The intentional ambiguity is probably due to avoidance of translation copyright requirements;

iii) none of the TTs bear the name of the translator, with only one exception: an editorial written by Peter Preston, former director of The Guardian, defending Spain against the attacks by tabloids at the time of the turbot conflict with the Canadian Government. In this case, the relevance of the ST sender is the defining factor for the appearance of the translator's name;

iv) all TTs share the same source: The Guardian (U.K. edition); this confers a certain unity and homogeneity to the corpus (Renouf, 1987:2), at least ideologically speaking ${ }^{17}$;

v) the author of the ST is explicitly quoted with no exception.

\section{Results}

Some of the results derived from this research on text binomials are worth seeing in detail. Since the scope of this study is necessarily limited due to its restricted nature (see Sinclair, 1991), we have selected some of the most interesting results obtained from the corpus. It is not our intention here to offer a list of the casuistry found in the corpus, and consequently we only include some of the most paradigmatic examples of the cases cited:

1. When there are omissions of text sections in the TTs, they are generally of three kinds: whole paragraphs, whole sentences, or phrases. This suggests that the translator is using the paragraph as intratextual translation unit, or alternatively -though less frequently, the sentence or the phrase. This seems to confirm Merino's theory (1994) that the semantic distribution of a text has a direct correspondence with discourse units, which are the ones chiefly affected by the changes observed in the corpus. Of the 67 texts studied, 42 of them presented relevant omissions, which in 34 cases were at the paragraph level, and in 8 cases at the sentence/phrase level. The cases of phrase omissions (noun phrases, appositions, etc.) are scarce, and fall mostly within the group of interlinguistic/intercultural inequivalences, which means that they are-so to say-omissions with an underlying cause. The remaining 25 texts have been translated with a degree of omission that is not globally relevant; 
2. The changes observed in units below the sentence level have a varied nature:

i) Adaptations: search of equivalents (mostly cultural) in the target system for elements which would otherwise be informationally opaque for the target reader. This indicates a primacy of the principle of acceptability (Toury, 1985 and 1995; Rabadán Álvarez, 1991a). Examples:

Figure 1: Examples of adaptations

\begin{tabular}{|c|l|l|}
\hline No. & \multicolumn{1}{|c|}{ ST } & \multicolumn{1}{|c|}{ TT } \\
\hline 76 & MPs & Diputados \\
\hline 78 & $\begin{array}{l}\text { Worth \$25 million (pounds 16 } \\
\text { million) }\end{array}$ & Por valor de 3.000 millones de pesetas \\
\hline 78 & With \$1 million raised & $\begin{array}{l}\text { Consiguió una subvención de 120 } \\
\text { millones de pesetas }\end{array}$ \\
\hline & $\$ 200$ million & $\begin{array}{l}200 \text { millones de dólares (ni más ni menos } \\
\text { que unos 23.600 millones de pesetas) }\end{array}$ \\
\hline 84 & 25 miles south of Zagreb & A cuarenta kilómetros al sur de Zagreb \\
\hline 85 & About 100 miles from Hiroshima & A unos 160 kms. de Hiroshima \\
\hline 99 & $\begin{array}{l}\text { Worth \$500,000 (pounds } \\
31.0,000)\end{array}$ & $\begin{array}{l}500.000 \text { dólares (unos 60 millones de } \\
\text { pesetas) }\end{array}$ \\
\hline 102 & About ten miles by 25 & Unos 16 kilómetros por cuarenta \\
\hline 109 & Prom pounds 10 & Más de 2.000 pesetas \\
\hline 128 & West Bank & $\begin{array}{l}\text { 350.000 libras (unos 70 millones de } \\
\text { pesetas) }\end{array}$ \\
\hline 129 & There is a brave new world & Colegios mayores \\
\hline
\end{tabular}

Source: own elaboration

ii) Paraphrases: explanations of elements which would otherwise be unmeaningful for the target reader. Again, the principle of acceptability is given priority. Examples:

Figure 2: Examples of cultural paraphrases

\begin{tabular}{|c|l|l|}
\hline No. & \multicolumn{1}{|c|}{ ST } & \multicolumn{1}{|c|}{ TT } \\
\hline 72 & Blitzkrieg & Guerra relámpago \\
\hline 76 & $\begin{array}{l}\text { Courtesy of a Conservative } \\
\text { government }\end{array}$ & $\begin{array}{l}\text { Gracias a un gobierno conservador } \\
\text { (Chamberlain) }\end{array}$ \\
\hline & A promise secured in Munich & $\begin{array}{l}\text { El acuerdo de Munich por el que se iba a } \\
\text { permitir a Hitler quedarse con los sudetes } \\
\text { tras la celebración de un plebiscito bajo } \\
\text { supervisión internacional }\end{array}$ \\
\hline & Michael Foot & El veterano izquierdista Michael Foot \\
\hline
\end{tabular}




\begin{tabular}{|c|c|c|}
\hline & Margaret Thatcher & $\begin{array}{l}\text { La ex primera ministra conservadora } \\
\text { Margaret Thatcher }\end{array}$ \\
\hline & Douglas Hurd & $\begin{array}{l}\text { El ex ministro de Exteriores "tory" } \\
\text { Douglas Hurd }\end{array}$ \\
\hline & Malcolm Rifkind & $\begin{array}{l}\text { El actual jefe de la diplomacia británica, } \\
\text { Malcolm Rifkind }\end{array}$ \\
\hline & John Reid & Su portavoz, John Reid \\
\hline 77 & European negotiator Carl Bildt & $\begin{array}{l}\text { El representante de la UE para la crisis } \\
\text { bosnia, Carl Bildt }\end{array}$ \\
\hline 92 & Gennifer Flowers & $\begin{array}{l}\text { Gennifer Flowers (la ex amante de } \\
\text { Clinton) }\end{array}$ \\
\hline & Appearance in 60 Minutes & $\begin{array}{l}\text { Aparición en el programa televisivo } 60 \\
\text { minutos }\end{array}$ \\
\hline 94 & $\begin{array}{l}\text { After the "glorious July } \\
\text { Revolution" }\end{array}$ & $\begin{array}{l}\text { Después de derrocar a la monarquía } \\
\text { hachemita que apoyaban los británicos }\end{array}$ \\
\hline 97 & The island's place in the zeitgeist & $\begin{array}{l}\text { El lugar que ocupa la isla en el espíritu de } \\
\text { la época }\end{array}$ \\
\hline 100 & User-friendliness & "la facilidad de relación con el usuario" \\
\hline 102 & $\begin{array}{l}\text { In some sense over Brent Spar we } \\
\text { were had }\end{array}$ & $\begin{array}{l}\text { En lo referente al asunto de Brent Spar } \\
\text { (la plataforma de Shell en el Mar del } \\
\text { Norte), Greenpeace nos engañó }\end{array}$ \\
\hline 110 & The first proton synchroton & Un sincrotón (acelerador de partículas) \\
\hline 120 & Fish and chips wrapping & $\begin{array}{l}\text { Papel de envoltorio para los "físh and } \\
\text { chips" (el pescado frito con patatas típico } \\
\text { en Inglaterra) }\end{array}$ \\
\hline 128 & The Haganah's elite unit & $\begin{array}{l}\text { La Hagana (ejército de resistencia creado } \\
\text { clandestinamente durante el mandato } \\
\text { británico) }\end{array}$ \\
\hline 133 & APEC accord & $\begin{array}{l}\text { Acuerdo de librecambio con los países } \\
\text { del Sureste Asiático y el Pacífico } \\
\text { (APEC) }\end{array}$ \\
\hline 134 & $\begin{array}{l}\text { Producer of RTE's Questions and } \\
\text { Answers Programme }\end{array}$ & $\begin{array}{l}\text { Productora de Preguntas y Respuestas, } \\
\text { programa radiofónico de la cadena RTE }\end{array}$ \\
\hline
\end{tabular}

Source: own elaboration

iii) Source element + explanation/literal translation: the original item is preserved in the translation and some kind of explanation is added; in most of these cases the source item has a referential function, which is probably why the translator thinks it necessary to keep it. Examples: 
Figure 3: Examples of source element + explanation/literal translation

\begin{tabular}{|c|c|c|}
\hline No. & ST & $\mathrm{TT}$ \\
\hline 70 & Medical Research Council(MRC) & $\begin{array}{l}\text { ElMedical Research Council, el Consejo } \\
\text { de Investigaciones Médicas (MRC) }\end{array}$ \\
\hline \multirow[t]{3}{*}{72} & Stalin's Letters to Molotov & $\begin{array}{l}\text { Stalin's Letters to Molotov (Las cartas de } \\
\text { Stalin a Molotov) }\end{array}$ \\
\hline & Let History Judge & $\begin{array}{l}\text { Let History Judge (Que juzgue la } \\
\text { historia) }\end{array}$ \\
\hline & Smolensk under Soviet rule & $\begin{array}{l}\text { Smolensk under Soviet rule (Smolensk } \\
\text { bajo el gobierno soviético) }\end{array}$ \\
\hline 75 & $\begin{array}{l}\text { A personal journey with Martin } \\
\text { Scorsese through American } \\
\text { movies }\end{array}$ & $\begin{array}{l}\text { "A personal joumey with Martin } \\
\text { Scorsese through American movies" (El } \\
\text { viaje personal de Martin Scorsese a } \\
\text { través de las películas americanas) }\end{array}$ \\
\hline 79 & $\begin{array}{l}\text { Hollywood wags call the movie } \\
\text { Kevin's Gate and Fishtar (in } \\
\text { honour of cinema's most glorious } \\
\text { disasters, Heaven's Gate and } \\
\text { Ishtar) }\end{array}$ & $\begin{array}{l}\text { Los bromistas de Hollywood llaman ya a } \\
\text { la película Kevin's gate (la puerta de } \\
\text { Kevin) y Fishtar en honor de dos de los } \\
\text { más gloriosos desastres de la historia del } \\
\text { cine: Heaven's Gate (la puerta del cielo) } \\
\text { e Ishtar }\end{array}$ \\
\hline \multirow[t]{2}{*}{92} & $\begin{array}{l}\text { The author of Scandal: The } \\
\text { Culture of Mistrust in American } \\
\text { Politics }\end{array}$ & $\begin{array}{l}\text { Autora de The Culture of Mistrust in } \\
\text { American Politics (La cultura de la } \\
\text { desconfianza en la política } \\
\text { estadounidense) }\end{array}$ \\
\hline & To Renew America & $\begin{array}{l}\text { "To Renew America" (Renovar Estados } \\
\text { Unidos) }\end{array}$ \\
\hline 118 & Tin Lizzie & El "Tin Lizzie" (Viejo Trasto) \\
\hline \multirow[t]{2}{*}{120} & Mostly Harmless & $\begin{array}{l}\text { Mostly Harmless (Inofensivo en líneas } \\
\text { generales) }\end{array}$ \\
\hline & Hitchiker's guide to the galaxy & $\begin{array}{l}\text { Hitchicker's guide to the galaxy (Guía } \\
\text { para autoestopistas de la galaxia) }\end{array}$ \\
\hline
\end{tabular}

Source: own elaboration

iv) Literal translations: the translator is giving priority to the principle of adequacy (Toury, 1985 and 1995; Rabadán Álvarez, 1991a) regardless of the transparency of the target text item. These instances are not frequent in the corpus, and in a few cases are due to the fact that the translator himself/herself comes across an opaque element. Examples: 
Figure 4: Examples of literal translations

\begin{tabular}{|c|l|l|}
\hline No. & \multicolumn{1}{|c|}{ ST } & \multicolumn{1}{|c|}{ TT } \\
\hline 60 & $\begin{array}{l}\text { International Brotherhood of } \\
\text { Teamsters, Chauffeurs, } \\
\text { Warehousemen and Helpers of } \\
\text { America }\end{array}$ & $\begin{array}{l}\text { Cofradía de Camioneros, Chóferes, } \\
\text { Almacenistas y Ayudantes de América }\end{array}$ \\
\hline 93 & State Examinations & Exámenes estatales \\
\hline 101 & It's true about the rain in Spain & Es cierto eso de la lluvia en España \\
\hline 115 & Ran around Kilroy-style & $\begin{array}{l}\text { Pasando de mano en mano, al estilo } \\
\text { Kilroy }\end{array}$ \\
\hline
\end{tabular}

Source: own elaboration

v) Full omissions of very specific cultural elements: in these cases, the translator has weighed the relative advantages of either adding a paraphrase or preserving opaque culturally-bound items and has finally decided not to translate the cultural references at all. This is one of the most frequent options in the corpus below the sentence level. Examples:

Figure 5: Examples of full omissions

\begin{tabular}{|c|c|c|}
\hline No. & ST & TT \\
\hline 71 & $\begin{array}{l}\text { General John Shalikashvili, the } \\
\text { US chief of staff }\end{array}$ & El jefe del Estado Mayor de EEUU \\
\hline 76 & $\begin{array}{l}\text { Callum McDonald, Labour MP } \\
\text { for the Western Isles }\end{array}$ & Callum McDonald, diputado laborista \\
\hline \multirow[t]{5}{*}{92} & $\begin{array}{l}\text { From the redemption of } \\
\text { televangelists Jimmy Swaggart } \\
\text { and Jim Bakker }\end{array}$ & $\varnothing$ \\
\hline & $\begin{array}{l}\text { A shared passion for politics, } \\
1957 \text { Ford Mustangs and junk } \\
\text { food }\end{array}$ & Una misma pasión por la comida basura \\
\hline & $\begin{array}{l}\text { She is called Callista and sings in } \\
\text { the Capital Hill choir }\end{array}$ & $\varnothing$ \\
\hline & $\begin{array}{l}\text { The parallel with the President's } \\
\text { legendary "I didn't inhale" (..) is } \\
\text { hard to resist. }\end{array}$ & $\varnothing$ \\
\hline & $\begin{array}{l}\text { Dwight Eisenbower's } \\
\text { "friendship" with his former army } \\
\text { chauffeuse }\end{array}$ & $\varnothing$ \\
\hline \multirow[t]{2}{*}{96} & $\begin{array}{l}\text { The Waco Branch Davidians did } \\
\text { something similar }\end{array}$ & $\varnothing$ \\
\hline & $\begin{array}{l}\text { Prague had only one terminally } \\
\text { brave Jan Palach in } 1968\end{array}$ & $\varnothing$ \\
\hline
\end{tabular}




\begin{tabular}{|c|l|l|}
\hline & $\begin{array}{l}\text { Bobby Sands won accolades in } \\
\text { Khomeini's Tehran }\end{array}$ & $\emptyset$ \\
\hline 98 & Like the early SDP in Britain & $\varnothing$ \\
\hline 114 & A jury at Cardiff crown court & La Corte \\
\hline 115 & The Donahue show & $\varnothing$ \\
\hline 119 & Oxbridge & $\varnothing$ \\
\hline 131 & Di, queen of all soap queens & $\varnothing$ \\
\hline
\end{tabular}

Source: own elaboration

vi) Expansions or additions of information: these cases are curious and very rare in other types of text transfer (literary translation, etc.). The translator seem to believe that the target reader a) needs more specific data to understand the text; b) has to be provided with the latest update on the news item, replacing all the information which is outdated by the time the text is translated and published in the target system. There are several cases of breaking news dealing with natural disasters in which the number of casualties or victions has been updated by the translator/reporter. Examples:

Figure 6: Examples of informative expansions and additions

\begin{tabular}{|l|l|l|}
\hline No. & \multicolumn{1}{|c|}{ ST } & \multicolumn{1}{|c|}{ TT } \\
\hline 73 & To uproot up to 40,000 civilians & Desterrar a 42.000 civiles \\
\hline & Dutch batallion of 410 men & Batallón holandés de 440 hombres \\
\hline & $\varnothing$ & $\begin{array}{l}\text { Como advertencia al contingente } \\
\text { holandés para que se mantuviese } \\
\text { apartado, fueron bombardeados dos de } \\
\text { sus destacamentos. Los serbios } \\
\text { disparaban con carros de combate, } \\
\text { cañones de 120 milímetros y morteros }\end{array}$ \\
\hline & $\begin{array}{l}\text { "El ejército de la República Serbia (de } \\
\text { Bosnia) y las fuerzas del Ministerio del } \\
\text { Interior harán todo lo posible para } \\
\text { conseguir el triunfo en la lucha armada } \\
\text { yroteger el territorio, el pueblo y el } \\
\text { estado serbios con miras a alcanzar una } \\
\text { paz justa con la mayor prontitud", } \\
\text { prometió }\end{array}$ \\
\hline 78 & $\begin{array}{l}\text { Arrollando tres posiciones holandesas, } \\
\text { robándoles dos de sus vehículos } \\
\text { acorazados y tomando 30 rehenes } \\
\text { holandeses }\end{array}$ \\
\hline $\begin{array}{l}\text { Overrunning three Dutch } \\
\text { positions and taking 30 Dutch } \\
\text { troops hostage }\end{array}$ & $\begin{array}{l}\text { Hallan un submarino japonés de la } \\
\text { Segunda Guerra Mundial con i46 } \\
\text { lingotes de oro en el Pacífico }\end{array}$ \\
\hline
\end{tabular}




\begin{tabular}{|c|l|l|}
\hline 95 & $\begin{array}{l}\text { Killing six people and wounding } \\
\text { at least 38 }\end{array}$ & $\begin{array}{l}\text { Murieron al menos siete personas y 33 } \\
\text { resultaron heridas }\end{array}$ \\
\hline A road accident near Sarajevo & $\begin{array}{l}\text { Un desa fortunado accidente (...) se } \\
\text { dirigían a Sarajevo por el Monte Igmán }\end{array}$ \\
\hline 100 & A mortar attack (...) & $\begin{array}{l}\text { Un ataque (...). Según las fuentes serbio } \\
\text { bosnias, un niño de ocho años resultó } \\
\text { muerto en este ataque }\end{array}$ \\
\hline Rolling Stones & $\begin{array}{l}\text { Microsoft pagó a los Rolling Stones casi } \\
1.500 \text { millones de pesetas por utilizar la } \\
\text { canción de 1981 "start me up" }\end{array}$ \\
\hline
\end{tabular}

Source: own elaboration

3. There are several remarkable examples of changes in the order and distribution of paragraphs in the texts. Though translators in general keep to the original order and typographical divisions of paragraphs, there are a few cases where the order has been altered or reversed. In most of these cases, the units transferred were larger than one paragraph, usually three paragraphs or more. Additionally, these changes are not random: they tend to respect the subject matter of each transferred unit, which suggests that the translator has made a previous mental distribution of the text in terms of topic/content. This probably means that translators, consciously or unconsciously, make a content outline of the text and this enables them to alter its distribution with a logical pattern. This contradicts some traditional theories which were not able to explain certain 'unmotivated changes' and put them down to the translator's random or unconscious choices, change of mood or simply translational caprice (Newmark, 1988a, 1988b). This coherent redistribution of the target texts seems to indicate that, whereas the physical unit of transfer is the paragraph, the unit of content seems to be realised in groups of paragraphs;

4. The previous feature seems to be confirmed by a second case of information redistribution by translators: when the TTs are very long, the body of the text is split into several subsections introduced by short headline-like headings. Again, this is not a random decision at all: as we will see in the discussion, the translator seems to be fully conscious of the genre requirements for newspaper texts within the Spanish polysystem; whereas long, unseparated texts with small typefaces are perfectly acceptable within the 'newspaper text' genre requirements in the British polysystem, it is not so within the Spanish polysystem, where newspaper texts usually have to be made 'visually attractive' and 'user-friendly'. Consequently, newspaper texts in Spanish are 'visually adapted' for the recipient in order to make them look appealing and inviting, so that they are read from beginning to end. Additionally, the dramatic and intriguing spirit of these added headings ensures that the reader will be 'dragged' to them and will at least read the first few paragraphs below the heading. These headings are coherently organized, since they introduce a topic change in the text, be it a new aspect of the issue being dealt with, a new item or simply expansions or clarifications on the content of the text. Examples: 
Figure 7: Thematic headings

\begin{tabular}{|c|l|l|}
\hline No. & \multicolumn{1}{|c|}{ ST } & \multicolumn{1}{|c|}{ TT thematic headings } \\
\hline 56 & Un triángulo amoroso con dudosas esquinas & $\begin{array}{l}\text { iAmantes? } \\
\text { Mucho más que una diosa } \\
\text { sexual }\end{array}$ \\
\hline 72 & Stalin en la intimidad & $\begin{array}{l}\text { Reacciones feroces } \\
\text { Peligro de guerra } \\
\text { Motivos económicos } \\
\text { Camaradas del jefe } \\
\text { El temor de Lenin } \\
\text { Anular a Trotski } \\
\text { El fiel Molotov }\end{array}$ \\
\hline 79 & Con el agua al cuello & $\begin{array}{l}\text { Un Mad Max sobre el agua } \\
\text { Volver a rodar } \\
\text { Otros grandes fracasos }\end{array}$ \\
\hline 84 & $\begin{array}{l}\text { Los vecinos del frente, salpicados por la guerra } \\
\text { de la Krajina }\end{array}$ & $\begin{array}{l}\text { Respuestas esporádicas } \\
\text { Refugio en el almacén }\end{array}$ \\
\hline 90 & La bomba del agua & $\begin{array}{l}\text { Riesgo ecológico } \\
\text { Tensiones sociales }\end{array}$ \\
\hline 92 & En la cama con el Tío Sam & $\begin{array}{l}\text { Un silencio cómplice } \\
\text { Tres trampas a evitar }\end{array}$ \\
\hline 93 & El clan sanguinario & $\begin{array}{l}\text { El erial iraquí } \\
\text { Solitario y cruel } \\
\text { Ritual violento }\end{array}$ \\
\hline 97 & Ibiza, una isla en un mar de éxtasis & $\begin{array}{l}\text { Estupendo si lo resistes } \\
\text { Música para empalmar }\end{array}$ \\
\hline
\end{tabular}

Source: own elaboration

5. Text closures, that is, sentences at the end of the STs fulfilling the role of finalising them, seem to be one more proof of the veracity of our hypothesis on the motivated nature of the alterations introduced by translators in the target texts. Whereas it is common to find single sentences as text closures in English (they usually have an emphatic role), this is not -as yet-a textual accepted genre convention in Spanish. This is why in all the texts under study, whenever there was a final sentence functioning as closure in the source text, it was systematically merged with the previous paragraph in the target text. This textual process of paragraph assimilation indicates that translators seem to be fully conscious of the target reader expectations as regards genre requirements and, by virtue of this constraint, automatically conform to them;

6. There a few relevant instances of what we have called 'thematic additions', which are expansions on content aspects inexistent in the STs. They are often focused on the particular vision of the news item in the target text culture, or they simply add preliminary information necessary to fully grasp the text from the target culture point of view. In some cases these 
additions are marked by the explicit heading 'apoyo', and in a few of these the author of the text section is quoted. In most of the studied cases, these textual additions are placed at the very end of the article, which might suggest an unwillingness by the translator to interrupt the natural thematic flow/evolution of the text; however, this is only a hypothesis, since it might also be due to the fact that it is much simpler to add information at the end of a text. Examples:

Figure 8: 'Apoyos' in the TTs

\begin{tabular}{|c|c|c|c|c|}
\hline No. & Text & Explicit 'apoyo' & Author & Location \\
\hline 72 & Stalin en la intimidad & , & $\varnothing$ & End \\
\hline 79 & Con el agua al cuello & , & $\varnothing$ & End \\
\hline 80 & $\begin{array}{l}\text { Los marcianos llegaron } \\
\text { ya }\end{array}$ & , & $\begin{array}{l}\text { Irene Hernández } \\
\text { Velasco }\end{array}$ & End \\
\hline 86 & $\begin{array}{l}\text { Durmiendo con tu } \\
\text { enemigo }\end{array}$ & -- & $\varnothing$ & $\begin{array}{l}\text { Beginning, } \\
\text { middle and } \\
\text { end }\end{array}$ \\
\hline 90 & La bomba del agua & , & $\begin{array}{l}\text { Juan Carlos de la } \\
\text { Cal }\end{array}$ & End \\
\hline 93 & El clan sanguinario & 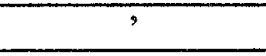 & R. Wurgaft & End \\
\hline 95 & $\begin{array}{l}\text { Siete muertos y treinta } \\
\text { y tres heridos en una } \\
\text { jornada sangrienta en } \\
\text { Sarajevo } \\
\end{array}$ & - & $\varnothing$ & Middle \\
\hline 99 & $\begin{array}{l}\text { Las monjas asesinas de } \\
\text { Ruanda }\end{array}$ & -- & $\varnothing$ & $\begin{array}{l}\text { Middle and } \\
\text { end }\end{array}$ \\
\hline 107 & $\begin{array}{l}\text { El mayor error de } \\
\text { Greenpeace en } \\
\text { Mururoa }\end{array}$ & , & $\varnothing$ & End \\
\hline 111 & $\begin{array}{l}\text { Greenpeace depura a } \\
\text { los responsables de la } \\
\text { captura de sus barcos } \\
\text { en Mururoa }\end{array}$ & -- & $\varnothing$ & End \\
\hline 116 & $\begin{array}{l}\text { Un romance sobre } \\
\text { papel }\end{array}$ & , & Beatriz Sartori & End \\
\hline 117 & $\begin{array}{l}\text { Un informe de la UE } \\
\text { afirma que los croatas } \\
\text { cometieron atrocidades }\end{array}$ & , & Javier Espinosa & End \\
\hline 123 & El poder y la gloria & ; & $\varnothing$ & End \\
\hline
\end{tabular}


7. Undoubtedly, the elements experiencing the most striking alterations are headlines. Whereas headlines tend to be informative and rather neutral in The Guardian, in El Mundo they are systematically turned into sensationalist, metaphorical, emotional, biased headlines. These try to make as strong an impact as possible on the reader, usually by introducing cultural elements of the target culture, thereby favouring acceptability as translation norm. Examples:

Figure 9: Examples of changes in headlines/leads

\begin{tabular}{|c|c|c|}
\hline No. & $\begin{array}{r}\text { ST } \\
\end{array}$ & TT \\
\hline 56 & Guess who came to dinner & $\begin{array}{l}\text { Un triángulo amoroso con dudosas } \\
\text { esquinas }\end{array}$ \\
\hline 70 & The $X$ files & Cobayas humanas en el Reino Unido \\
\hline 75 & $\begin{array}{l}\text { Cannes film festival: wise guys of the } \\
\text { movies }\end{array}$ & De la mano de Marty por el cine \\
\hline 78 & $\begin{array}{l}\text { US team finds gold-laden Japanese } \\
\text { submarine } 51 \text { years after sinking }\end{array}$ & La joya hundida \\
\hline 79 & Dances with turkeys & Con el agua al cuello \\
\hline 81 & It coulda been a contender & Perseguido por la maldición \\
\hline 83 & $\begin{array}{l}\text { Croatia's war wagged for blood and } \\
\text { soil }\end{array}$ & $\begin{array}{l}\text { Zagreb mueve ficha en el tablero } \\
\text { balcánico }\end{array}$ \\
\hline 84 & Wistful ballads to the tune of death & $\begin{array}{l}\text { Los vecinos del frente, salpicados por la } \\
\text { guerra de Krajina }\end{array}$ \\
\hline 93 & Saddam's enemy within & El clan sanguinario \\
\hline 98 & In homage to Dallas & Perot vuelve a la carga \\
\hline 104 & The road from tough talk to air raids & ¿Por fin atacan! \\
\hline 107 & Fury as greens admit fiasco & $\begin{array}{l}\text { E1 mayor error de Greenpeace en } \\
\text { Mururoa }\end{array}$ \\
\hline 108 & $\begin{array}{l}\text { The priest, the Angel of Death and the } \\
\text { whispered distress of a small Irish } \\
\text { town }\end{array}$ & El "gatillazo" del padre Kennedy \\
\hline 114 & Olympic coach jailed for rapes & Un violador al borde de la piscina \\
\hline 115 & White and wronged & Guerra étnica en el Washinton Post \\
\hline 116 & Drawing on the rebel within & $\begin{array}{l}\text { Un dibujante que vivió rápido, murió } \\
\text { joven y tuvo un cadáver bonito }\end{array}$ \\
\hline 118 & On the wagon & Volkswagen patas arriba \\
\hline 120 & The ways of the word & Cuando el mundo sea una red \\
\hline 122 & Demon at the heart of black America & El dia del orgullo negro \\
\hline 129 & Slave new world? & Tras el oropel de la TV digital \\
\hline 130 & Gossip and baloney in very high places & Del viejo orden a la nueva monarquía \\
\hline 132 & $\begin{array}{l}19 \text { more Ogonis face hanging as } \\
\text { Nigerian major shows who's boss }\end{array}$ & Golpean a quienes guardan luto \\
\hline
\end{tabular}




\begin{tabular}{|l|l|l|}
\hline 134 & Airing grievances & Divorcio en los medios irlandeses \\
\hline 136 & One winded president & Yeltsin perdió sus primarias \\
\hline
\end{tabular}

Source: own elaboration

As can be seen in the examples, the translation of these headlines closely resembles that of film names, where the decisive factor for the degree of faithfulness or creativity is the interest aroused in the addressee. Again, translators seem to be fully aware of the fact that only striking headings earn readers' attention and fulfil their primary objective in the target culture: being read from beginning to end. The interest of the reader is additionally ensured by the introduction of what we have called 'thematic headings', which are also sensationalist in nature and distribute the text for the reader.

\section{Discussion}

Both the body of the text and the headline have experienced major changes in translation in the corpus studied, though of a different nature and in different degrees. As regards pragmatic factors, the target reader seems to be the factor with a fundamental bearing on the translation process; this is demonstrated in the corpus by several changes which we believe are probably due to this principle. Semiotic considerations are also the cause of several changes; in this case, genre conventions in the target culture seem to be the most influential parameter. In our opinion, these changes reflect the awareness of translators as regards semiotic and pragmatic factors in the process of transfer:

(1) omissions and full omissions: translators regard the information provided unnecessary or irrelevant for the text recipient, either because the addressee is supposed to know it in advance, because it refers to cultural mismatches or because the addressee might not fully understand the information. Additionally, the fact that the omissions usually correspond with the semantic distribution of the text in the form of discourse units (paragraphs, sentences or phrases) is not coincidental: it reflects both the ability of the translator to readily build a mental outline of the underlying semantic evolution of the text and his/her concern for the natural flow of the text. The translator does not wish to alter this flow noticeably, and thus the changes s/he introduces follow logical principles and are not random or unmotivated. Furthermore, this proves the fact that translators are perfectly capable of automatically analysing texts and dividing them into semantic and discoursive pieces before translating; this is probably an unconscious process that takes seconds, but the very fact that the changes observed in the corpus present an identical pattern indicates that the changes obey coherent principles. Besides, the full omissions found in the corpus coincide with cultural elements alien to the target culture which would clearly have required long explanations in the TTs; again, 
translators respect TT conventions and requirements: extensive explanations are not usually acceptable in newspaper texts;

(2) paraphrases and explanations: most of them are found in cases where the ST segment would have been unmeaningful for the target reader. Obviously, the translator is: i) favouring the pragmatic factor 'target reader', which seems to be a major feature in the communication process for the translator, and ii) adhering to the target genre conventions, in this case to the principle that newspaper texts have to be made easy for the reader (what we have called 'textual comfort'), readily accessible and understandable and also pleasing to read (in this case, by avoiding opaque elements that might hinder the comprehension process);

(3) preservation of the source element + literal translation: almost all the instances observed in the corpus belong to the same category; they include ST items (mainly book or film titles) which are referential in nature. This is the reason why the translator, fully aware of this function, decides to keep both altematives in the TTs: the original element and a transparent, literal translation. Again, the translators are making the text easier and readily accessible for the target reader, providing him/her with all the information s/he might need, a basic semiotic priority in the corpus studied;

(4) literal translations: the transiators are seemingly favouring adequacy; this results from the fact that in a reduced number of cases the elements concerned are opaque for the translator himself/herself, which is why s/he decides to adhere to the original as much as possible;

(5) expansions and additions: there are several instances where the translator has provided the reader with data that were not present in the ST. In most cases, these pieces of information are updates on the STs; this means that translators are clearly giving priority to the principle of acceptability, thereby pragmatically promoting the target system (and reader) in their translation;

(6) distribution changes: this is one of the elements where the respect of translator for the semantic evolution of the text is more openly shown. Whenever translators alter the order of the original, they keep to the subject matter of each transfer unit, and thus change the order of whole discourse units, not just physical units (parapgraphs). Again, as previously stated, this suggests that translators make a previous mental distribution of the text in terms of topic/content. The most striking case is that of additional headings in the TTs: when STs are extremely long, translators seem to be conscious that these texts are not welcome in the Spanish polysystem. Consequently, the body of the target text is split into several subsections introduced by short headline-like headings. Once more, the translator 
respects genre requirements for newspaper texts within the Spanish polysystem, where long, unseparated newspaper texts with small typefaces would not be textually successful. Within the Spanish press environment, newspaper texts have to be made 'visually attractive' and 'user-friendly'. This seems to be the reason why the Spanish newspaper texts in the corpus have been 'visually adapted' by the translators in order to make them look appealing and inviting. Besides, the dramatic and intriguing spirit of these headings arouse the interest of the Spanish reader and s/he will at least have a look at the first few paragraphs below the heading. Furthermore, these headings respect the thematic distribution of the text, which confirms the drastic bearing of semiotic and pragmatic contraints in the transfer;

(7) text closures are one more proof of the motivated nature of the alterations introduced by translators in the target texts of the corpus. Whereas it is common to find emphatic single sentences as text closures in newspaper texts in English, this is not a currently accepted textual convention in Spanish. This is why in all the texts under study, the final closure sentences in the STs have merged with the previous paragraph in the TTs. This paragraph assimilation indicates the awareness of and concern for genre contraints by translators;

(8) headlines: these are doubtless the items experiencing the highest degree of alterations. Most source headlines have been transformed into a completely new headline in Spanish. This creativity process is by no means unmotivated; again, it aims at including the typically expected - or tolerated - features of headlines in Spanish: emotional impact on the reader, sensationalism, biased content, metaphorical nature, etc.

\section{Conclusion}

The results obtained from the categories analysed seem to indicate that translators have a very clear idea of what is acceptable and what is not acceptable in the target system, both as regards the particular genre they are translating from and into, and the targeted reader of the text.

Many of the apparently 'radical' changes that have taken place in the process of translation of newspaper texts in the corpus have proved to stand in relation with pragmatic and semiotic considerations. Not only have translators predicted the targeted readers of the TTs and adjusted the texts to their expectations, but they have also kept in mind genre requirements and applied them to the translated texts.

Thus, pragmatic and semiotic restrictions seem to be the two guiding parameters behind the occurrence of 'translation incidences' in newspaper binomials, and not - as traditional 
translation theory would probably have argued - mere random choices or incoherent equivalences by the translators.

\section{Notes}

1. Nord (1991: 28), to quote but one example, does not feel happy with this theory: "according to my concept of translation, which is doubtless conditioned by the conventional concept of transiation I have grown up with (...) a TT production that is not based on, or bound to, a given source text (...) cannot be called a translation".

2. "Translation-oriented" for Nord (1991, 1992: 39 and 42).

3. Unfortunately, this results in a heavy reliance on dictionaries by students (Fraser, 1999: 25).

4. Plus an extra one suggested by Alcaraz Varó (1990: 120): 'completeness'. Roberts (1996b: 37-38) prefers to include this condition in the general requirements of any text: "any passage, spoken or written, of any length that forms $a$ unified whole and communicates a message" [my emphasis].

5. We will leave aside the long-standing debate over the various conceptual and terminological alternatives for 'context' (see Roberts, 1996a and 1996b; Hartmann, 1980: 19; Nord, 1991: 37 and 1992; Van den Broeck, 1978; Crystal and Davy, 1969/1990; Sinclair, 1991: 171; Leckie-Tarry, 1995: 17; Halliday and Hasan, 1997 [1976], etc.).

6. We will not consider paralinguistics here, since we are studying written texts exclusively.

7. Curiously enough, given the special nature of newspaper translations in Spain this is not a very relevant factor in the translation process. Usually the client imposes the translation terms/conditions (see Nord, 1991: 11; Baker, 1992: 31; Hewson and Martin, 1991: 23; SnellHornby, 1991: 9; Benitez, 1992: 29; Venuti, 1992: 2, etc.); however, in the translation of newspaper texts it is mostly -with few exceptions- in-house reporters who produce the translations without receiving any additional payment for it; in practical terms, this means that the process of transfer is considerably more 'anonymous' and that the translation restrictions are not overt (with the obvious exception of space limitations; see Sanderson, 1995 and Samaniego Fernández, 2000).

8. See also: Bühler, 1934; Eigenwald, 1974; Jacobson, 1975; Grosse, 1976; Werlich, 1976; Longacre and Levinsohn, 1978; Sager et al., 1980; Delisle, 1980; Hartmann, 1980 and 1981; Beaugrande and Dressler, 1981/1994; Snell and Crampton, 1993; Biber, 1989; James, 1989; Rabadán Âlvarez, 1991a; Larson, 1991; Vilarnovo and Sánchez, 1992; Baker, 1992; Hervey and Higgins, 1992; Neubert and Shreve, 1992; Gommlich, 1993; Hatim and Mason, 1990 and 1997; Reiss and Vermeer, 1996; Stubbs, 1996; Roberts, 1996a and 1996b; Sigley, 1997, etc. We do not include some of these references in the bibliography due to space restrictions.

9. Data provided by Donna Halfpenny-Peters, manager of the Information Department in The Guardian.

10. Date provided by Jorge Fernández. deputy director of El Mundo.

11. Great Britain is the only country in Europe to exceed two million metric tons of press paper per year. Circulation figures per 100 inhabitants are close to 400 papers against 82 in Spain. These figures match the ones obtained by the Audit Bureau of Circulations.

12. "Tabloids are superficial in their treatment of events. The vocabulary range of some of these papers is limited; the emphasis is upon quick reading; and much of their material is sensationalized and trivialized. It cannot be said that the British populars at the lower end of the 
market are deeply instructive, or concerned with raising the critical consciousness of their readers" (Oakland 1989/1995: 274).

13. Dunnett even divides the press in Great Britain (1988: 128) into two broad categories: 'high brow' or 'middle brow', depending on the degree of linguistic accessibility.

14. There are several articles published in The Guardian which describe quite openly the ideological stance of El Mundo. In "Crusading editor tap-dances on the grave of Gonzalez" (16/07/95), The Guardian says: "El Mundo is only six years old, but (...) its fiercely critical stance against the Socialist government of Felipe Gonzalez has seen its circulation increase almost threefold. (...) with a succession of scoops about corruption in high places, it has achieved a daily circulation of almost 300,000 , establishing it as Spain's third biggest-selling paper. Pedro J. Ramirez has created a successful newspaper. It's nothing like The Washington Post, as he seems to think, but it sells like hot cakes. The war between El Pais and El Mundo is not only a battle for circulation, it also involves bad blood, what Spaniards term 'mala leche': 'El Pais (...) after, 1982 never questioned the Socialist government in any serious way. El Pais hasn't broken any of the major scandals of the past 12 years. That's a great lesson to us and we won't fall into the same trap'".

15. The Guardian, 29/08/95; El Mundo, 24/08/97.

16. "(..) a translator should (...) translate into his own mother tongue or into a language of which he or she has a mastery equal to that of his or her mother tongue" (Shuttleworth and Cowie, 1997: 42).

17. The Guardian calls El Mundo "Spanish sister paper" $(22 / 05 / 95$, p.2). In fact, both newspapers belong to the same consortium: "(...)[ElMundo] in which the Guardian Media Group, which owns The Observer, has a 2 per cent share" (The Observer 16/06/95, p.19). Both El Mundo and The Guardian are part of the RCS group (Rizzoli Corriere della Sera), which owns seven large business groups, among which are some well known publishing firms: Ediciones Orbis, Milano Press, Edibook, RCS France, Euphon, Unidad Editorial (Unedisa), Fabripress, Ediciones de Castilla y León (Edical), Amica Verlag, Max Verlag and Co., etc.

\section{Works Cited}

Albaladejo Mayordomo, Tomás (2000): "El texto político de escritura periodística: la configuración retórica de su comunicación". Clac 1, 1-7. Available on Internet, <http: //www.ucm.es/info/circulo/nol>.

Alcaraz Varó, Enrique (1990): Tres paradigmas de la investigación lingüistica. Alcoy: Marfil.

Álvarez Lugrís, A. (1996): "Traducción: texto, contexto, cotexto". In M.T. Caneda Cabrera y J. Pérez Guerra, eds., Os estudios ingleses no contexto das novas tendencias. Vigo: Universidad, 211-242.

Asociación para la Investigación de Medios de Comunicación (A.I.M.C.). Available on Internet, < http: //www.aimc.es/aimc.html>.

Ayala, F. (1985): "La retórica del periodismo". In F. Ayala, La retórica del periodismo y otras retóricas. Madrid: Espasa Calpe, 37-64.

Baker, Mona (1992): In Other Words. A Coursebook on Translation. London: Routledge.

. (1993): "Corpus Linguistics and Translation Studies - Implications and Applications". In M. Baker, G. Francis and E. Tognini-Bonelli (eds.), Text and Technology (In Honour of John Sinclair). Amsterdam/Philadelphia: John Benjamins, 233-250. 
. (1995), "Corpora in Translation Studies: An Overview and Some Suggestions for Future Research". Target 7(2): 223-243.

. (1996): "Corpus-Based Translation Studies. The Challenges that Lie Ahead". In H. Somers (ed.), Terminology, LSP and Translation. Studies in Language Engineering in Honour of Juan C. Sager. Amsterdam: John Benjamins, 175-186.

Beaugrande, R. de and W.U. Dressler (1981): Introduction to Text Linguistics. London and New York: Longman, translated from the German original (1972).

Benitez, Esther (1992): "La situación del traductor profesional (en España)". In P. Fernández Nistal (coord.), Estudios de traducción. Valladolid: I.C.E., 23-32

Biber, D. (1989): "A Typology of English Texts". Linguistics 27, 3-43.

Birch, D. (ed.)(1995): Language and Context. A Functional-Linguistic Theory of Register. London/New York: Pinter.

Broeck, R. Van Den (1978): "The Concept of Equivalence in Translation Theory: Some Critical Reflections". In J.S. Holmes, J. Lambert and R. Van Den Broeck (eds.), Literature and Translation. New Perspectives in Literary Studies. Leuven: Acco, $29-47$.

Bühler, K. (1985): Teoria del lenguaje. Madrid: Alianza Universidad, translated from the German original (1934).

Casasús, J.M. and L. Núñez Ladevéze (1991): Estilo y géneros periodísticos. Barcelona: Ariel.

Chamosa González, J.L. (1997): "Crítica y evaluación de traducciones: elementos para su discusión". In P. Fernández Nistal and J.M. Bravo Gozalo (coord.), Aproximaciones a los estudios de traducción. Valladolid: S.A.E., 29-50.

Chesterman, A. (1993): "From 'Is' to 'Ought': Laws, Norms and Strategies in Translation Studies". Target 5(1): 1-20.

Colina, S. (1997): "Syntax, Discourse Analysis, and Translation Studies". Babel 43(2): 126-137.

Considine, D.M. (1974): Chemical and Process Technology Encyclopedia. New York: McGraw Hill.

Crystal, D and D. Davy (1969/1990): Investigating English Style. London: Longman.

Delisle, J., H. Lee-Jahnke and M.C. Cormier (1999): Terminologie de la traduction. Translation Terminology. Terminología de la traducción. Terminologie der Übersetzung. Amsterdam: John Benjamins Publishing Co.

Dijk, Teun A. Van (1983a): "Discourse Analysis: Its Development and Application to the Structure of News". Journal of Communication 33(2): 20-43.

. (1983b): "Estructuras textuales de las noticias de prensa". Análisis 7/8: 77-105. . (1985a): Discourse and Communication. New Approaches to the Analysis of Mass Media Discourse and Communication. Berlin/New York: De Gruyter.

. (ed.)(1985b): Handbook of Discourse Analysis. San Diego: Academic Press. (1988a): News Analysis. New Jersey: Lawrence Erlbaum Associates. . (1988b): News As Discourse. New Jersey: Lawrence Erlbaum Associates. . (ed.)(1997): Discourse as Structure and Process. London: Sage Publications.

Di Virgilio, P.S. (1984): "The Sense of a Beginning: the Dynamics of Context in Translation". Meta 29(2): 115-127.

Duff, B. and R. Schindler (1984): Language and Style in the Press. A Reader's Guide to British Newspapers. London: Collins ELT.

Dunnett, P.J.S. (1988): The World Newspaper Industry. New York: Croom Heim.

Eco, U. (1976): A Theory of Semiotics. London and Basingstoke: Macmillan. 
(1984): Semiotics and the Philosophy of Language. London: Macmillan.

El-Shiyab, S. (1994): "Translation of Texts and Their Contexts". Babel 40(4): 232-238.

Even-Zohar, Ithamar (1978): "The Position of Translated Literature within the Literary

Polysystem". In J.S. Holmes, J. Lambert and R. Van Den Broeck (eds.), Literature and

Translation. New Perspectives in Literary Studies. Leuven: Acco, 117-127.

. (1979): "Polysystem Theory". Poetics Today 1(1-2): 287-310.

$1-7$.

(1981): "Translation Theory Today". A Call for Transfer Theory". Poetics Today 2(4),

(1990): "Translation and Transfer". Poetics Today 11(1): 73-78.

. (1997): "The Making of Culture Repertoire and the Role of Transfer". Target 9(2): 355-

363.

Freeborn, D. (1996): Style. Text Analysis and Linguistic Criticism. London: MacMillan Press Limited.

Fowler, R. (1991): Language in the News: Discourse and Ideology in the Press. Oxford: Routledge.

Fraser, J. (1999): "The Translator and the Word: The Pros and Cons of Dictionaries in Translation". In G. Anderman and M. Rogers (eds), Word, Text, Translation. Liber Amicorum for Peter Newmark. London: Multilingual Matters Ltd., 25-34.

García-Mon Marañes, B. and M.J. Ramírez Lafita (1992): "Los medios de comunicación escritos en la sociedad española". Revista Española de Investigaciones Sociológicas 57, 87-108.

Garrido Medina, Joaquín C. (1994): Idioma e Información. La lengua española de la comunicación. Madrid: Síntesis.

. (ed.)(1999): La lenguay los medios de comunicación. Madrid: Serviciode Publicaciones

de la Universidad Complutense de Madrid.

Gaudino-Falleger, L. (2000): "Notas sobre la sintaxis de los titulares de las revistas femeninas". Clac 2, 1-10. Internet, <http: //www.ucm.es/info/circulo/no2>.

Gómez Soliño, J.S. (1996): "La organización jerárquica de los textos desde una perspectiva

funcional". In M.T. Caneda Cabrera and J. Pérez Guerra (eds.), Os estudios ingleses no contexto das novas tendencias. Vigo: Universidad, 43-68.

Halliday, M.A.K., and R. Hasan (1989): Language, Context and Text. Aspects of Language in a Social Semiotic Perspective. Oxford: Oxford University Press.

Hartmann, R.R.K. (1980): Contrastive Textology. Heidelberg: Julius Groos Verlag. Studies in Descriptive Linguistics 5.

Hatim, Basil and lan Mason (1990): Discourse and the Translator. London: Longman. . (1996): "The method in their adness: the juggling of texts, discourse and genres in the language of adevrtising and implications for the translator". In A. Hurtado Albir (ed.), La enseñanza de la traducción. Castellón: Publicacions de la Universitat Jaume I, 109-126. (1997): The Translator as Communicator. London: Routledge.

Hermans, Theo (ed.)(1985a): The Manipulation of Literature. Sydney: Croom and Helm. . (1985b): "Translation Studies and a New Paradigm". In T. Hermans (ed.), 7-15. . (1993): "On Modelling Translation: Models, Norms and the Field of Translation". Livius 4: 69-88.

Hetherington, A. (1981): Guardian Years. London: Chatto.

Hewson, L. and J. Martin (1991): Redefining Translation. The Variational Approach. London: Routledge. 
House, Juliane (1981, $2^{\text {nd }}$ ed.) [1977]: A Model for Translation Quality Assessment. Tübingen: Gunter Narr Verlag.

Hurtado Albir, Amparo (ed.)(1996a): La enseñanza de la traducción. Castellón: Publicacions de la Universitat Jaume I.

. (1996b): "La enseñanza de la traducción directa 'general'. Objetivos de aprendizaje y metodología". In A. Hurtado Albir (ed.), 31-56.

(Dir.) (1999): Enseñar a traducir. Metodología en la formación de traductores $e$ intérpretes. Madrid: Edelsa.

Isenberg, H. (1987): "Cuestiones fundamentales de tipología textual". In E. Bernárdez (comp.), Lingüística del texto. Madrid: Arco/Libros, 95-129.

Jacobson, R. (1960): "Linguistics and Poetics". In T.A. Sebeok (ed.), Style in Language. Cambridge (Mass.): The M.I.T. Press.

Jucker, A.H. (1992): Social Stylistics: Syntactic Variation in British Newspapers. Berlin: Mouton de Gruyter.

Keeble, R. (1994): The Newspapers Handbook. London: Routledge.

Kosir, M. (1988): "Towards a Theory of Journalistic Text Form". Media, Culture and Society 10: 345-361.

Lambert, J. and H. Van Gorp (1985): "On Describing Translations". In T. Hermans (ed.), The Manipulation of Literature. Sydney: Croom and Helm, 42-53.

Leckie-Tarry, Heien (1995): Language and Context. A Functional Linguistic Theory of Register. London/New York: Pinter.

Leech, G. (1983): Principles of Pragmatics. London and New York: Longman.

Levinson, S.C. (1983): Pragmatics. Cambridge: Cambridge University Press.

López García, A. (1996): Escritura e información. La estructura del lenguaje periodístico. Madrid: Cátedra.

Lozano, J., C. Peña Marín, G. Abril (1982): Análisis del discurso. Hacia una semiótica de la interacción textual. Madrid: Cátedra.

Malmkjær, K. (ed.)(1991): The Linguistics Encyclopedia. London/New York: Routledge.

Martín Vivaldi, G. (1973/1984, $3^{\text {rd }}$ ed.): Géneros periodísticos. Reportaje, crónica, artículo: análisis diferencial. Madrid: Paraninfo.

Martínez Albertos, J.L. (1989): El lenguaje periodístico. Madrid: Paraninfo.

Martínez Vallvey, F. (1996): Herramientas periodísticas. Salamanca: Librería Cervantes.

Merino Álvarez, Raquel (1994): Traducción, tradición y manipulación. León: Universidades de León y del País Vasco.

Neubert, A. and G.M. Shreve (1992): Translation as Text. Kent: Kent State University.

Nida. E.A. (1999): "The Role of Contexts in Translating". In G. Anderman and M. Rogers (eds), Word, Text, Translation. Liber Amicorum for Peter Newmark. London: Multilingual Matters Ltd., 79-83.

Nord, Christiane (1991): Text Analysis in Translation. Theory, Methodology and Didactic Application of a Model for Translation-Oriented Text Analysis. Amsterdam/Atlanta: Rodopi, translation by Christiane Nord and Penelope Sparrow.

. (1994): "Las funciones comunicativas y su realización textual en la traducción". Sendebar 5: 85-103.

. (1995): "Text-Functions in Translation: Titles and Headings as a Case in Point". Target 7(2): 261-284. 
(1997): Translating as a Purposeful Activity: Functionalist Approaches Explained. Manchester: St. Jerome Publishing.

Núñez Ladevéze, L. (1979): El lenguaje de los 'media'. Introducción a una teoría de la actividad periodística. Mađrid: Pirámide.

(1991): Manual para periodismo. Veinte lecciones sobre el contexto, el lenguaje y el texto de la información. Barcelona: Ariel.

. (1995): Introducción al periodismo escrito. Barcelona: Ariel.

Oakland, J. (1995, $3^{\text {rd }}$ ed.) [1989]: British Civilization. An Introduction. London/New York: Routledge.

Parker, S.P. (1991): Diccionario McGraw Hill de química. Bilingüe español-inglés, EnglishSpanish. New York: McGraw Hill.

Rabadán Álvarez, Rosa (1991a): Equivalencia y traducción. Problemática de la equivalencia translémica inglés-español. León: Universidad de León.

. (1991b): "The Unit of Translation Revisited". In M.L. Larson(ed.), Translation: Theory and Practice. Tension and Interdependence. ATA series, vol.V. New York: SUNY at Binghamton, 38-48.

(1996), "El papel de la lingüística en los estudios de traducción: usos y aplicaciones". In P. Fernández Nistal and J.M. Bravo Gozalo (coord.), A Spectrum of Translation Studies. Valladolid: S.A.E., 91-103.

Rabadán Álvarez, Rosa and F.J. Fernández Polo (1996): "Lingüística aplicada a la traducción". In M. Fernández Pérez (coord.), Avances en lingüística aplicada. Santiago: Universidade, 105-145.

Rabadán Álvarez, Rosa and Teresa Guzmán (1987): "Las inequivalencias lingüísticas en la traducción inglés-español". In XI Congreso Aedean, Translation Across Cultures, León: Universidad.

Reiss, Katharina (1992): "Teorías de la traducción y su relevancia para la práctica". Sendebar 3, 25-37.

Reiss, Katharina and Hans J. Vermeer (1996): Fundamentos para una teoria funcional de la traducción. Madrid: Akal Ediciones, translated from the German original (1984).

Roberts, Roda (1992): "The Concept of Function of Translation and Its Application to Literary Texts". Target 4(1): 1-16.

. (1996a): "Dictionaries, Dictionary-making and Translation". In P. Fernández Nistal and J. M. Bravo Gozalo (coord.), A Spectrum of Translation Studies. Valladolid: S.A.E., 9-35. (1996b): "Text and Translation". In P. Fernández Nistal and J. M. Bravo Gozalo (coord.), A Spectrum of Translation Studies. Valladolid: S. A.E., 37-53.

Rogers, M. (1999): "Translating Terms in Text: Holding on to Some Slippery Customers". In G. Anderman and M. Rogers (eds), Word, Text, Translation. Liber Amicorum for Peter Newmark. London: Multilingual Matters Ltd., 104-118.

Sager, J.C., D. Dungworth and P.F. McDonald (1980): English Special Languages. Wiesbaden: Oscar Brandstetter Verlag.

Samaniego Fernández, Eva (2000): Diseño y aplicación de un marco de análisis de la traducción de la metáfora. Alicante: Tesis doctoral inédita.

Schäffner, C. (ed.)(1999): Translation and Norms. London: Multilingual Matters Ltd. 
Séguinot, C. (1999), "Translation Theory, Translating Theory and the Sentence". In G. Anderman and M. Rogers (eds), Word, Text, Translation. Liber Amicorum for Peter Newmark. London: Multilingual Matters Ltd., 84-94.

Shuttleworth, M. and M. Cowie (1997): Dictionary of Translation Studies. Manchester: St. Jerome Publishing.

Shveitser, A.D. (1997); Contrastive Stylistics: News Media Style in English and in Russian. Las Palmas de Gran Canaria: Servicio de Publicaciones de la Universidad de Las Palmas de Gran Canaria.

Sigley, R. (1997): "Text Categories and Where You Can Stick Them: A Crude Formality Index". International Journal of Corpus Linguistics 2(2): , 199-237.

Sinclair, John (1991): Corpus, Concordance, Collocation. Oxford: Oxford University Press.

Snell-Hornby, Mary (1988): Translation Studies: An Integrated Approach. Amsterdam: John Benjamins Publishing Company.

. (1991): "The Professional Translator of Tomorrow: Language Specialist or All-Round Expert?". In C. Dollerup and A. Loddegaard (eds.), Teaching Translation and Interpreting. Training, Talent and Experience. Amsterdam/Philadelphia: John Benjamins Publishing Company, 9-22.

Statistical Yearbook. Annuaire Statistique $\left(1993,38^{\text {th }}\right.$ ed.). New York: United Nations/Nations Unies.

Steel, B. (1971): "Headline Classes in Journalistic Spanish" An Exercise in Register Analysis". Ibero-Romania 2: 174-187.

Stubbs, M. (1996): Text and Corpus Analysis. Oxford: Blackwell Publishers.

Toury, Gideon (1981): "Translated Literature: System, Norm, Performance. Toward a TTOriented Approach to Literary Translation". Poetics Today 2(4): 9-27. . (1985): "A Rationale for Descriptive Translation Studies". In T. Hermans (ed.), The Manipulation of Literature. Sydney: Croom and Helm, 16-41. . (1995): Descriptive Translation Studies and Beyond. Amsterdam/Philadelphia: John Benjamins.

Tricàs Preckler, M. (1982): "Texto y contexto en el proceso de traducción". Cuadernos de Traducción e Interpretación 1: 39-45.

Venuti, L. (ed.)(1992): Rethinking Translation. Discourse, Subjectivity, Ideology. London/New York: Routledge.

Vilarnovo, A. and J.F. Sánchez (1992): Discurso, tipos de texto y comunicación. Pamplona: Ediciones Universidad de Navarra.

Willis, J. (1990): Journalism: State of the Art. New York/Connecticut/London: Praeger Publishers. 